\title{
Peracetic Acid and Chlorine Dioxide for Postharvest Control of Monilinia laxa in Stone Fruits
}

\author{
M. Mari, T. Cembali, E. Baraldi, and L. Casalini, CRIOF, University of Bologna, V. F. Re, 8-40126 Bologna, Italy
}

\begin{abstract}
Mari, M., Cembali, T., Baraldi, E., and Casalini, L. 1999. Peracetic acid and chlorine dioxide for postharvest control of Monilinia laxa in stone fruits. Plant Dis. 83:773-776.

The effects of different concentrations of peracetic acid (PAA; 62.5, 125, 250, 500, and 1,000 $\mu \mathrm{g} / \mathrm{ml}$ ) and chlorine dioxide $\left(\mathrm{ClO}_{2} ; 12.5,25,50,100\right.$, and $\left.200 \mu \mathrm{g} / \mathrm{ml}\right)$ on germination of Monilinia laxa conidia were tested. Conidia germination was related to the concentration of chemical product used, as well as duration of treatment. Complete inhibition of germination was observed with PAA at $500 \mu \mathrm{g} / \mathrm{ml}$ after $5 \mathrm{~min}$ of contact with conidia and with $\mathrm{ClO}_{2}$ at $50 \mu \mathrm{g} / \mathrm{ml}$ after $1 \mathrm{~min}$ of contact with conidia. The results of in vitro tests were confirmed by inoculation of fruits with treated conidia. The PAA treatment also was effective $1 \mathrm{~h}$ after pathogen inoculation but only on plums, for which a $1,000 \mu \mathrm{g} / \mathrm{ml}$ treatment significantly reduced decay incidence by $50 \%$. In a semicommercial test, pathogen conidia dipped for $20 \mathrm{~min}$ in PAA at $250 \mu \mathrm{g} / \mathrm{ml}$ or $\mathrm{ClO}_{2}$ at $10 \mu \mathrm{g} / \mathrm{ml}$ or for $5 \mathrm{~min}$ in PAA at $250 \mu \mathrm{g} / \mathrm{ml}$ were completely inhibited, and no brown rot was observed in inoculated wounded nectarines and plums.
\end{abstract}

Additional keywords: postharvest decay, sanitizing product

Brown rot caused by Monilinia laxa (Aderh. \& Ruhl.) Honey is one of the most important diseases found on all commercially grown Prunus species in Italy (19). The pathogen develops on fruit in orchards, in packinghouses, during transit and marketing, and in the homes of consumers. Elsewhere, postharvest fungicide treatment of fruit is a routine practice, especially if the fruit is to be stored or shipped over long distances (5). In Italy, however, postharvest treatments are not authorized, hence brown rot control is mainly limited to preharvest measures that are unsatisfactory. Losses attributed to M. laxa are considerable, and under certain climatic conditions, brown rot results in substantial damage and market losses (14).

The demand for alternative postharvest disease management practices that could reduce consumer and environmental risks has increased in recent years because of the appearance of resistant strains $(11,16)$ and increasing concerns about hygiene and public health. In the search for alternatives to chemical control, natural compounds with fungitoxic properties are of interest and could be useful for controlling postharvest fruit rots, including Monilinia spp. $(8,13,22)$. Moreover, calcium hydroxide also is effective in reducing brown rot incidence, caused

Corresponding author: M. Mari

E-mail: mari@agrsci.unibo.it

Accepted for publication 12 May 1999.

Publication no. D-1999-0621-03R

(C) 1999 The American Phytopathological Society by $M$. fructicola, on unwounded peach fruit (5).

The effectiveness of chlorine in decay prevention has been known for some time (2), although several limitations exist (i.e., the rapid drop in fungistatic activity of chlorine in the presence of organic substances that modify the $\mathrm{pH}$ of the solution). For this reason, chlorine dioxide $\left(\mathrm{ClO}_{2}\right)$ appears to be preferable, because it is more stable than chlorine and is not corrosive (16). $\mathrm{ClO}_{2}$ has been used commercially for bacterial control of postharvest fungal decay (15) in pea corn (20), pear (18), and peach (17).

Limited data are available on the effects of peracetic acid (PAA) on postharvest fruit decay. PAA has been tested on tomatoes (10) and degreened oranges (6) with conflicting results.

Our study was conducted to evaluate the effects of several concentrations of $\mathrm{ClO}_{2}$ and PAA on M. laxa conidia germination and control of fruit decay under laboratory and semicommercial conditions.

\section{MATERIALS AND METHODS}

Brown rot pathogen. M. laxa was isolated from decayed nectarines stored commercially. An isolate with high pathogenic activity on peaches, nectarines, and plums was grown as a monoconidial culture on V8 agar (V8A: $250 \mathrm{ml}$ of $\mathrm{V} 8$ vegetable juice and $40 \mathrm{~g}$ of agar per $1,000 \mathrm{ml}$ of distilled water). Petri dishes were incubated at $25^{\circ} \mathrm{C}$ with $12 \mathrm{~h}$ of dark/12 h of light cycles for 10 to 14 days. A conidial suspension was prepared by washing colonies grown on V8A in sterile water and Tween $80(0.05 \%)$. Suspension concentrations were adjusted with a hemacytometer.
Fruits studied. Fruits used in this study included nectarines (cv. Stark Red Gold) and plums (cv. Black Ambert) obtained from a local packinghouse. Fruits were free of wounds and rot and were homogeneous in maturity and size. Fruits were stored at $1{ }^{\circ} \mathrm{C}$ and inoculated within 5 days of harvesting.

Chemical products. Pure PAA solution (Aldrich Chemical Company, Milwaukee, WI) and a chlorine-based product containing 2\% $\mathrm{ClO}_{2}$ (Acquabio-SL, Acquacontrol, Bologna, Italy) were used in all trials. The exact concentration of available chlorine was measured spectrophotometrically during each treatment with a reagent kit (Spectroquant, Merck, Darmstadt, Germany).

Effects of PAA and $\mathrm{ClO}_{2}$ on conidia germination. PAA and $\mathrm{ClO}_{2}$ were added to $M$. laxa suspensions to obtain final pathogen concentrations of $6 \times 10^{5}$ conidia per $\mathrm{ml}$. $\mathrm{ClO}_{2}$ was added to obtain final concentrations of available chlorine of $12.5,25,50$, 100 , and $200 \mu \mathrm{g} / \mathrm{ml}$, and PAA solution was added to obtain final concentrations of 62.5 , $125,250,500$, and $1,000 \mu \mathrm{g} / \mathrm{ml}$. All mixtures were kept at $2 \pm 1^{\circ} \mathrm{C}$. After $20 \mathrm{~s}$ and $1,2,5$, and 10 min of conidia contact with sanitizing solution, $0.5 \mathrm{ml}$ of suspension was taken from each concentrate and diluted 100fold. Aliquots $(0.1 \mathrm{ml})$ of suspensions were spread on petri dishes containing $25 \mathrm{ml}$ of malt extract agar and incubated for $24 \mathrm{~h}$ at $20^{\circ} \mathrm{C}$. A suspension of untreated conidia $(6 \times$ $10^{3}$ conidia per $\mathrm{ml}$ ) was used as the control. Ten duplicate samples from one dish were used per treatment. Conidia germination was determined by observing with a light microscope at least 300 conidia from both treatments and the control. Data were expressed as percent conidia germination inhibited compared with the control. The experiment was conducted twice.

Effects of PAA- and $\mathrm{ClO}_{2}$-treated conidia inoculum on fruits. Nectarines and plums were wounded with a scalpel by removing $3 \times 3 \times 3$-mm blocks of tissue. Wounds were made on the equator of each fruit: two wounds per nectarine and one wound per plum. Each wound was inoculated with $20 \mu \mathrm{l}$ of conidia suspension $(6 \times$ $10^{3}$ conidia per $\mathrm{ml}$ ) that was treated with PAA and $\mathrm{ClO}_{2}$ at the concentrations described above. Control fruits were inoculated with $20 \mu$ of conidia suspension $\left(6 \times 10^{3}\right.$ conidia per $\mathrm{ml}$ ) that was not treated with PAA or $\mathrm{ClO}_{2}$. For nectarines, each test group consisted of 3 sets of 5 fruits each, for a total of 30 wounds. For plums, each test group consisted of 3 sets of 25 fruits each, for a total of 75 wounds. Fruits were 
placed on trays and wrapped in polyethylene bags. Lesion diameter was measured after 6 days at $20^{\circ} \mathrm{C}$. The experiment was conducted twice.

Effects of PAA treatment on inoculated fruits. Nectarines and plums were wounded with a sterile needle (two wounds per fruit at the equator) and inoculated by dipping for $1 \mathrm{~min}$ in a $M$. laxa suspension of $8 \times 10^{3}$ conidia per ml. After inoculation, fruits were kept at $20^{\circ} \mathrm{C}$ for $1 \mathrm{~h}$, dipped for $20 \mathrm{~s}$ or 1 min in PAA solution (500 or $1,000 \mu \mathrm{g} / \mathrm{ml})$. Concentration used depended on test group. Control fruits were inoculated with $M$. laxa and, after inoculation, were dipped in water for 1 min under



Fig. 1. Inhibition of Monilinia laxa conidia germination when suspended in peracetic acid solution for varied exposure times and treatment concentrations. Aliquots $(0.1 \mathrm{ml})$ of a 1:99 dilution of $M$. laxa suspension were spread on malt extract agar dishes and incubated for $24 \mathrm{~h}$ at $20^{\circ} \mathrm{C}$. Ten samples from one dish were used per treatment. Conidia germination was determined by observing at least 300 conidia under a light microscope for both treatments and the control. Data were expressed as percent germination inhibition in treated conidia compared with the control.

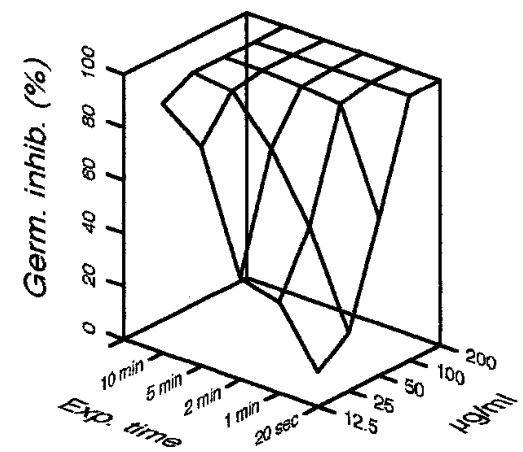

Fig. 2. Inhibition of Monilinia laxa conidia germination when suspended in a chlorine dioxide solution at varied exposure times and treatment concentrations. Aliquots $(0.1 \mathrm{ml})$ of a $1: 99$ dilution of $M$. laxa suspension were spread on malt extract agar dishes and incubated for $24 \mathrm{~h}$ at $20^{\circ} \mathrm{C}$. Ten samples from one dish were used per treatment. Conidia germination was determined by observing at least 300 conidia under a light microscope for both treatments and the control. Data were expressed as percent germination inhibition of treated conidia compared with the control. the same conditions used for treated fruits. Fruits were kept at $20^{\circ} \mathrm{C}$ for 6 days, and the percentage of infected wounds was determined. The single test group consisted of 3 sets of 25 fruits each, for a total of 150 wounds per group. The experiment was performed twice.

Effects of $\mathrm{PAA}$ and $\mathrm{ClO}_{2}$ treatments in a semicommercial test. Nectarines and plums were dipped in 50-L tanks containing $M$. laxa at a concentration of $2 \times 10^{3}$ conidia per $\mathrm{ml}$. At the start of the test, control fruits were dipped for $1 \mathrm{~min}$ before adding sanitizing products to the tanks; $\mathrm{ClO}_{2}$ or PAA was used at concentrations of 10 and $250 \mu \mathrm{g} / \mathrm{ml}$ respectively. Fruits were dipped for $1 \mathrm{~min}$ at $1,4,9$, and $19 \mathrm{~min}$ after addition of chemicals. Fruits were incubated and examined as previously described. Each treatment consisted of 3 sets of 150 fruits each, for a total of 900 wounds. The experiment was performed twice.

Data analysis. A completely randomized design was used in each test. Statistical analysis was performed using the SYSTAT 5.2 software package (21). All data on the percentage of infected fruits were subjected to one-way analysis of variance. Before analysis of data, homogeneity of variance was tested by Bartlett's test. Mean separation was performed using the least significant difference test $(P=0.05)$.

\section{RESULTS}

Effects of PAA and $\mathrm{ClO}_{2}$ on conidia germination. The effects of $\mathrm{PAA}$ and $\mathrm{ClO}_{2}$ on $M$. laxa conidia germination were directly related to the concentration of chemical and duration of treatment. For PAA, the lowest concentration tested $(62.5 \mu \mathrm{g} / \mathrm{ml})$ produced only a small $(22.7 \%)$ reduction in conidia germination, even after $10 \mathrm{~min}$ of exposure (Fig. 1). At 250 and $500 \mu \mathrm{g} / \mathrm{ml}$, conidia growth was inhibited by $70.6 \%$ after $2 \mathrm{~min}$ and $59.3 \%$ after $1 \mathrm{~min}$, respectively. The highest concentration of PAA $(1,000 \mu \mathrm{g} / \mathrm{ml})$ reduced conidia germination to $50.55 \%$ after only $20 \mathrm{~s}$ of treatment. To- tal inhibition of conidia germination was observed after 5 and $10 \mathrm{~min}$ of exposure to PAA at $500 \mu \mathrm{g} / \mathrm{ml}$.

For $\mathrm{ClO}_{2}, 100 \mu \mathrm{g} / \mathrm{ml}$ completely inhibited conidia germination, regardless of duration of dipping (Fig. 2). At $50 \mu \mathrm{g} / \mathrm{ml}, \mathrm{ClO}_{2}$ reduced the rate of germination by more than $50 \%$ after only $20 \mathrm{~s}$ of exposure. Lowering the concentration of $\mathrm{ClO}_{2}$ to $25 \mu \mathrm{g} / \mathrm{ml}$ resulted in $56.9 \%$ inhibition of conidia germination after $1 \mathrm{~min}$ of exposure. The lowest concentration of $\mathrm{ClO}_{2}(12.5 \mu \mathrm{g} / \mathrm{ml})$ continued to effect germination after $5 \mathrm{~min}$ of treatment, resulting in $82.5 \%$ inhibition of germination.

Effects of PAA- and $\mathrm{ClO}_{2}$-treated conidia inoculum on fruits. Fruits inoculated with treated conidia developed lesions with diameters varying according to the concentration of sanitizing chemical used in the treatment, duration of exposure to the treatment, and species of inoculated fruit. Fruits inoculated with conidia treated for $1 \mathrm{~min}$ with PAA at $1,000 \mu \mathrm{g} / \mathrm{ml}$ developed the smallest lesions (Fig. 3). In fact, under these treatment conditions there was almost total disease control in both nectarines (Fig. 3A) and plums (Fig. 3B). Nectarines inoculated with conidia treated for $20 \mathrm{~s}$ with $\mathrm{ClO}_{2}$ at $100 \mu \mathrm{g} / \mathrm{ml} \mathrm{did}$ not develop brown rot (Fig. 4A). Similar results were obtained for plums inoculated with conidia treated for 2 min with $\mathrm{ClO}_{2}$ at $200 \mu \mathrm{g} / \mathrm{ml}$ (Fig. 4B).

Effects of PAA treatment on inoculated fruits. Treatment of previously inoculated nectarines with PAA did not result in any reduction in incidence of infected wounds, although there were some significant reductions in infected wounds in plums (Table 1). Dipping inoculated fruits for $20 \mathrm{~s}$ and $1 \mathrm{~min}$ in a PAA solution of $1,000 \mu \mathrm{g} / \mathrm{ml}$ significantly reduced the percentage of rot to 22.7 and $24 \%$, respectively, whereas $50.7 \%$ of wounds in control fruits were infected. The disease incidence obtained after dipping inoculated fruit in PAA at $500 \mu \mathrm{g} / \mathrm{ml}$ was intermediate between disease incidence



\section{Exposure time}

Fig. 3. Effects of peracetic acid (PAA) treatment on conidia of Monilinia laxa inoculated into wounded nectarines (A) and plums (B). Wounds were inoculated with $20 \mu \mathrm{l}$ of a conidial suspension $\left(6 \times 10^{3}\right.$ conidia per ml) previously treated with PAA at $0,250,500$, and $1,000 \mu \mathrm{g} / \mathrm{ml}$. Lesion diameters were recorded after 6 days at $20^{\circ} \mathrm{C}$. Each point is the average of at least 30 wounds; vertical bars represent standard errors. 
in the control and in the $1,000 \mu \mathrm{g} / \mathrm{ml}$ PAA treatment (Table 1).

Effects of PAA and $\mathrm{ClO}_{2}$ treatment in a semicommercial test. On nectarines and plums, decay was significantly reduced when conidia remained in a PAA solution of $250 \mu \mathrm{g} / \mathrm{ml}$ for $2 \mathrm{~min}$ (Table 2). Exposure of conidia to $\mathrm{ClO}_{2}$ at $10 \mu \mathrm{g} / \mathrm{ml}$ for $2 \mathrm{~min}$ reduced incidence of infected wounds by more than $55 \%$. When exposure of conidia to chemicals was prolonged to $4 \mathrm{~min}$, no decay developed on nectarines or plums dipped for $1 \mathrm{~min}$ in PAA at $250 \mu \mathrm{g} / \mathrm{ml}$ or for $19 \mathrm{~min}$ in $\mathrm{ClO}_{2}$ at $10 \mu \mathrm{g} / \mathrm{ml}$ (Table 2).

\section{DISCUSSION}

Previously PAA has been used almost exclusively as a sanitizing agent in different sterilization processes, such as heatsensitive equipment (3) and ultrafiltration membranes in water-treatment systems (1). The results of our in vitro trials confirmed considerable fungicidal activity against $M$. laxa by PAA. Germination of conidia was inhibited by PAA treatments; the degree of inhibition depended on PAA concentration and duration of exposure. The best results were observed with PAA at $1,000 \mu \mathrm{g} / \mathrm{ml}$ and an exposure time of at least $2 \mathrm{~min}$.

When fruits were inoculated with $M$. laxa conidia exposed to PAA at $250 \mu \mathrm{g} / \mathrm{ml}$ for $5 \mathrm{~min}$ or $500 \mu \mathrm{g} / \mathrm{ml}$ for $2 \mathrm{~min}$, no decay developed in either nectarines or plums. PAA at $50 \mu \mathrm{g} / \mathrm{ml}$ also had high fungicidal activity against Aspergillus niger and Penicillium roqueforti in tomatoes after $10 \mathrm{~min}$ of exposure (10) but not against blue mold, caused by $P$. digitatum, in oranges, even when PAA was used at $500 \mu \mathrm{g} / \mathrm{ml}$ (6).

Recently, chlorine dioxide has replaced chlorine in some sanitizing processes, because several disadvantages limit the use of chlorine, including its unpleasant odor. $\mathrm{ClO}_{2}$ in in vitro trials was active against $M$. laxa. Exposure of conidia to $\mathrm{ClO}_{2}$ at $50 \mu \mathrm{g} / \mathrm{ml}$ for 1 min completely prevented conidia germination, confirming the results obtained with other postharvest pathogens, such as Botrytis cinerea, Mucor piriformis, and $P$. expansum (18). However, when fruits were inoculated with treated conidia, treatment effects varied as a function of exposure time, concentration of $\mathrm{ClO}_{2}$, and species tested.

Chlorine only kills by contact, not systemically, and is effective only on exposed fungal propagules, such as those suspended in water or on the surface of fruit. Chlorine does not kill pathogens under the fruit skin or after infection has occurred. Chlorine did not control decay caused by $M$. piriformis when used after inoculation (4). One hour after inoculation the fungicidal activity of PAA was significant on plums but not nectarines. The different fungicidal response on nectarines and plums may be explained by the decomposition rate of PAA, which depends on the nature and $\mathrm{pH}$ of the fruit surface (10).

Prolonged (20 $\mathrm{min}$ ) exposure of M. laxa conidia to solutions of PAA $(250 \mu \mathrm{g} / \mathrm{ml})$ or
$\mathrm{ClO}_{2}(10 \mu \mathrm{g} / \mathrm{ml})$ caused devitalization of conidia, which was indicated by the absence of brown rot on nectarines and plums wounded and dipped for $1 \mathrm{~min}$ in sanitizing solution. The results obtained in the semicommercial tests appear to have practical applications. In the packinghouse, wash water used as the handling medium appears be a source of inoculum for plums and nectarines fruits. Introducing a biologically active concentration of $\mathrm{ClO}_{2}$ or PAA into the wash water could reduce the level of conidia with- out the need for pesticides. Biocidal $\mathrm{ClO}_{2}$ or PAA also could be successfully used during hydrocooling, because the technique involves leaving fruits for 30 to $45 \mathrm{~min}$ or more in chilled $\left(4^{\circ} \mathrm{C}\right)$ water. This amount of time would allow both $\mathrm{ClO}_{2}$ and PAA to act more effectively against $M$. laxa. Moreover, prerefrigeration of wash water, which limits weight loss and permits quick chilling of fruits, frequently can make fruits more susceptible to decay, especially if the fruit is not sold within a short time (19).



Exposure time

Fig. 4. Effects of chlorine dioxide $\left(\mathrm{ClO}_{2}\right)$ treatment on conidia of Monilinia laxa inoculated into wounded nectarines (A) and plums (B). Wounds were inoculated with $20 \mu \mathrm{l}$ of a conidial suspension $\left(6 \times 10^{3}\right.$ conidia per ml) previously treated with $\mathrm{ClO}_{2}$ at $0,50,100$, and $200 \mu \mathrm{g} / \mathrm{ml}$. Lesion diameters were recorded after 6 days at $20^{\circ} \mathrm{C}$. Each point is the average of at least 30 wounds; vertical bars represent standard errors.

Table 1. Effect of peracetic acid (PAA) treatment on stone fruits ${ }^{\mathrm{y}}$ inoculated with Monilinia laxa

\begin{tabular}{lccc}
\hline \multirow{2}{*}{$\begin{array}{l}\text { PAA concentration } \\
(\boldsymbol{\mu g} / \mathbf{m l})\end{array}$} & Exposure time $(\mathbf{s})$ & Nectarine & Plum \\
\cline { 3 - 4 } & $\ldots$ & $23.8 \mathrm{a}$ & $50.7 \mathrm{a}$ \\
500 & 20 & $23.1 \mathrm{a}$ & $35.3 \mathrm{~b}$ \\
500 & 60 & $18.8 \mathrm{a}$ & $39.3 \mathrm{~b}$ \\
1,000 & 20 & $16.3 \mathrm{a}$ & $22.7 \mathrm{c}$ \\
1,000 & 60 & $21.3 \mathrm{a}$ & $24 \mathrm{c}$ \\
\hline
\end{tabular}

${ }^{\mathrm{y}}$ Wounded fruits were inoculated by dipping for $1 \mathrm{~min}$ in a $M$. laxa suspension $\left(8 \times 10^{3}\right.$ conidia per $\mathrm{ml})$. After inoculation $(1 \mathrm{~h})$, fruits were dipped for $20 \mathrm{~s}$ or $1 \mathrm{~min}$ in PAA solution at 500 or 1,000 $\mu \mathrm{g} / \mathrm{ml}$. Fruits inoculated with the pathogen and dipped in water served as controls. All fruits were stored at $20^{\circ} \mathrm{C}$ for 6 days. A single test group consisted of 3 sets of 25 fruits each, for a total of 150 wounds per group. Data from two experiments were pooled.

${ }^{z}$ Values in each column that are not significantly different based on the LSD test $(P=0.05)$ are followed by the same letter.

Table 2. Effect of peracetic acid (PAA) and chlorine dioxide $\left(\mathrm{ClO}_{2}\right)$ treatments on stone fruits inoculated with Monilinia laxa under semicommercial conditions

\begin{tabular}{|c|c|c|c|c|}
\hline \multirow{3}{*}{$\begin{array}{l}\text { Time exposed to } \\
\text { conidia (min) }\end{array}$} & \multicolumn{4}{|c|}{ Infected wounds $^{\mathrm{y}, \mathrm{z}}(\%)$} \\
\hline & \multicolumn{2}{|c|}{ Nectarine } & \multicolumn{2}{|c|}{ Plum } \\
\hline & PAA & $\mathrm{ClO}_{2}$ & PAA & $\mathrm{ClO}_{2}$ \\
\hline 0 & $35.6 \mathrm{a}$ & $35.6 \mathrm{a}$ & $65.6 \mathrm{a}$ & $65.6 \mathrm{a}$ \\
\hline 2 & $6.6 \mathrm{~b}$ & $15.6 \mathrm{~b}$ & $10 \mathrm{~b}$ & $26.7 \mathrm{~b}$ \\
\hline 5 & $0 \mathrm{c}$ & $6.7 b c$ & $0 \mathrm{~b}$ & $6.8 \mathrm{bc}$ \\
\hline 10 & $0 \mathrm{c}$ & $5.7 \mathrm{bc}$ & $0 \mathrm{~b}$ & $7.8 \mathrm{bc}$ \\
\hline 20 & $0 \mathrm{c}$ & $0 \mathrm{c}$ & $0 \mathrm{~b}$ & $0 \mathrm{c}$ \\
\hline
\end{tabular}

${ }^{y}$ Control fruits were dipped for $1 \mathrm{~min}$ in a $M$. laxa suspension $\left(2 \times 10^{3}\right.$ conidia per ml), to which $\mathrm{ClO}_{2}(10 \mu \mathrm{g} / \mathrm{ml})$ or PAA $(250 \mu \mathrm{g} / \mathrm{ml})$ was added. Treated fruits were dipped for $1 \mathrm{~min}$ at $1,4,9$, and $19 \mathrm{~min}$ after chemical product was added. All fruits were stored for 6 days at $20^{\circ} \mathrm{C}$. A single test group consisted of 3 sets of 150 fruits each, for a total of 900 wounds per group. Data from two experiments were pooled.

${ }^{\mathrm{z}}$ Values in each column that are not significantly different based on the LSD test $(P=0.05)$ are followed by the same letter. 
Chlorine dioxide is inactivated by organic matter (9), although to a lesser degree than other chlorine compounds, and progressively deteriorates, with a consequent drop in antimicrobial activity, making frequent monitoring of $\mathrm{pH}$ and chlorine concentration necessary. $\mathrm{ClO}_{2}$ is not corrosive on packinghouse equipment, and it is effective over a wide $\mathrm{pH}$ range. However, the $10 \mu \mathrm{g} / \mathrm{ml}$ concentration necessary to obtain significant fungicidal activity would be too expensive, and therefore, effective lower concentrations are desirable (18).

PAA has greater stability, faster biocidal properties, is not $\mathrm{pH}$ dependent (7), and has lower toxicity than $\mathrm{ClO} 2$. For example, the oral $50 \%$ lethal dose in rats is $1,540 \mathrm{mg} / \mathrm{kg}$ (12). Problems associated with corrosiveness could be reduced by use of commercial formulations containing a lower concentration of PAA and no sulfuric acid, making it suitable for use with stainless-steel equipment (3).

Sanitizing solutions can be integrated easily with hydrocooling systems to reduce postharvest fruit decay. However, the low temperature used in hydrocooling reduces the efficacy of both $\mathrm{ClO}_{2}$ and PAA. As with other chemical processes, sanitation takes place at a slower rate as temperatures fall, although it is not completely inhibited. The current study provides useful information for determining the optimal conditions for control of brown rot on stone fruits by biocidal PAA and $\mathrm{ClO}_{2}$ products. However, further research is required to better define effective procedures.

\section{LITERATURE CITED}

1. Alasri, A., Valverde, M., Roques, C., Michel, G., Cabassud, C., and Aptel, P. 1993. Sporocidal properties of peracetic acid and hydrogen peroxide, alone and in combination, in comparison with chlorine and formaldehyde for ultrafiltration membrane disinfection. Can. J. Microbiol. 39:52-60.

2. Baker, K. F., and Heald, F. D. 1932. Some problems concerning blue mold in relation to cleaning and packing of apples. Phytopathology 22:897-898.

3. Baldry, M. G. C. 1983. The bactericidal, fungicidal and sporocidal properties of hydrogen peroxide and peracetic acid. J. Appl. Bacteriol. 54:417-423.

4. Bertrand, P., and Saulie-Carter, J. 1979. Postharvest decay control of apples and pears after immersion dumping. Oreg. State Univ. Exp. Stn. Spec. Rep. 545.

5. Biggs, A. R., El-Kholi, M. M., EL-Neshawy, S., and Nickerson, R. 1997. Effects of calcium salts on growth, polygalacturonase activity, and infection of peach fruit by Monilinia fructicola. Plant Dis. 81:399-403.

6. Brown, G. E. 1987. Effect of experimental bacterial disinfectants applied to oranges on postharvest decay. Pages 20-22 in: Proc. Fla. State Hortic. Soc. 100. American Society for Horitcultural Science, Miami Beach, FL.

7. Brown, G. E., and Schubert, T. S. 1987. Use of Xanthomonas campestris pv. vesicatoria to evaluate surface disinfectants canker quarantine treatment of citrus fruit. Plant Dis. 71:319323.

8. Caccioni, D. R. L., and Guizzardi, M. 1994. Inhibition of germination and growth of fruit and vegetable postharvest pathogenic fungi by essential oil components. J. Essent. Oil Res. 6:173-179.

9. Dychdala, G. R. 1983. Chlorine and chlorine compounds. Pages 157-182 in: Disinfection, Sterilization, and Preservation. 3rd ed. S. S. Block, ed. Lea \& Febiger Co., Philadelphia.

10. Greenspan, F. I., and MacKellar, D. G. 1951. The application of peracetic acid germicidal washes to mold control of tomatoes. Food Technol. 5:95-97.

11. Guizzardi, M., Caccioni, D., and Pratella, G. C.
1995. Resistance monitoring of Monilinia laxa (Aderh. \& Ruhl.) Honey to benzymidazole and dicarboxymides in postharvest stage. J. Plant Dis. Prot. 102:86-90.

12. Lewis, R. J., and Tatken, R. L. 1980. Registry of Toxic Effects of Chemical Substances, vol. 2. Page 252. U.S. Department of Health and Human Services, National Institute for Occupational Safety and Health, Washington, DC.

13. Mari, M., Iori, R., Leoni, O., and Marchi, A. 1993. In vitro activity of glucosinolates-derived isothiocyanates against postharvest fruit pathogen. Ann. App. Biol. 123:155-164.

14. Pratella, G. C., Caccioni, D., and Mari, M. 1995. Strategie innovative nella difesa postraccolta delle pesche. Pages 27-45 in: Proc. 22nd Conv. Peschicolo. CCIAA, Ravenna, Italy.

15. Roberts, R. S., and Reymond, S. T. 1994 Chlorine dioxide for reduction of postharvest pathogen inoculum during handling of tree fruits. Appl. Environ. Microbiol. 60:2864-2868.

16. Sanoamuang, N., and Gaunt, R. E. 1995. Persistence and fitness of carbendazim- and dicarboximide-resistant isolates of Monilinia fructigena (Wint.) Honey in flowers, shoots and fruit of stone fruit. Plant Pathol. 44:448-457.

17. Sozzi, A., and Gorini, F. L. 1982. Il biossido di cloro per prevenire i marciumi delle pesche. Ann. IVTPA 13:117-122.

18. Spotts, R. A., and Peters, B. B. 1980. Chlorine and chlorine dioxide for control of d'Anjou pear decay. Plant Dis. 64:1095-1097.

19. Tosi, C., Spada, G., Ponti, I., and Tonini, G. 1996. I marciumi da Monilia su pesche nettarine e percoche. Riv. Frutticolt. \& Ortofloric. 7/8:9-15.

20. Welch, J. L., and Folinazzo, J. F. 1959. Use of chlorine dioxide for cannery sanitation and water conservation. Food Technol. 13:179-182.

21. Wilkinson, L. 1990. SYSTAT: The System for Statistics. SYSTAT, Inc., Evanston, IL.

22. Wilson, C. L., Franklin, J. D., and Otto, B. E. 1987. Fruit volatiles inhibitory to Monilinia fructicola and Botrytis cinerea. Plant Dis. 71: 316-319. 